\title{
THE TRANSFORMATION OF INDUSTRIAL RELATIONS IN EASTERN GERMANY
}

\author{
ULRICH JÜRGENS, LARISSA KLINZING, and LOWELL TURNER*
}

\begin{abstract}
Citing case studies based on interviews they conducted in 1991 and 1992 with labor representatives and managers at six eastern German manufacturing firms, the authors argue that the future could hold either vigor and growth or stagnation and permanent second-class status for the economy and labor movement in eastern Germany, depending largely on actor strategy and choice. The rapid spread of privatization and open markets is tending to undermine unions' influence, on the one hand; but on the other hand, institutional transfer from former West Germany (especially of codetermination law and centralized, regionallevel collective bargaining) is giving unions and works councils increased possibilities for leverage.
\end{abstract}

QINCE the collapse of "Realsozialismus" Din the former German Democratic Republic (GDR), the five new eastern states of unified Germany have become a land of liberated citizens and pioneers, and at the same time a land of despair and dashed hope. Dreams and disaster roam side by side, and nowhere is this more true than at the workplace. As millions of workers are displaced and thrown out of work, millions of others cling to old or

\footnotetext{
* Ulrich Jürgens is Senior Research Fellow at the Wissenschaftszentrum Berlin für Sozialforschung; Larissa Klinzing is a Senior Lecturer at Humboldt Universität; and Lowell Tumer is Assistant Professor at the School of Industrial and Labor Relations at Cornell University. Financial support for this study was provided by the Wissenschaftszentrum Berlin, the Institute for Collective Bargaining at the School of Industrial and Labor Relations at Cornell University, and the Western Societies Program at Cornell University. Earlier versions of this paper were presented at the German Studies Association Conference in Los Angeles, Sepuember 26-29, 1991, and at the American Political Science Association meeting in Washington, D.C., August 29-September 1, 1991. The authors thank Michael Fichter, Andy Markovits, and John Windmuller for useful comments on the earlier drafts.
}

new jobs, sometimes in despair, sometimes with high expectations. In great numbers, these workers have elected new works councillors and joined western unions, in hopes of combating pervasive employment insecurity and promoting better working conditions and rising pay.

The purpose of this paper is to examine the prospects for plant-level industrial relations and workers' interest representation (unions and works councils) in the five new states of the former GDR. This question is a critical one because (1) the stability and nature of industrial relations are directly related to the success of work reorganization and industrial restructuring (Katz and Sabel 1985; Streeck 1987; Jürgens, Malsch and Dohse 1989); (2) success or failure in the eastern states will have a major impact on the successful (West) German model of industrial relations and on union strength; and (3) the future stability of German industrial relations and especially the economic and political strength of German unions can be expected to have a major influence on the 
prospects for a "social Europe," as European economic integration proceeds.

The evidence we examine concerns essential questions of industrial relations in eastern Germany: the extent of union organization, works council elections, relations between works councils and unions and between works councils and management, and collective bargaining outcomes and union economic and social policy influence.' We use these findings as indicators of the prospects for unions, works councils, and the (West) German industrial relations model in eastern Germany. The findings are based on broad study and analysis of economic and industrial relations developments in eastern Germany from 1990 to 1992 , as well as on interview-intensive case studies of industrial relations at six large eastern firms, conducted in 1991 and 1992.

\section{The Argument: \\ Different Outcomes Possible}

Based on the available evidence and our own interviews in workplaces in eastern Germany, we argue that perspectives both of high hope and of despair are solidly rooted in contemporary reality. In the interaction between markets, politics, and institutions, different outcomes are possible. On the one hand, the spread of markets and the accompanying political decisions of the Kohl regime (accelerated currency union, rapid privatization, massive layoffs) are tending to weaken unions and works councils. As unemployment rises toward a quarter of the eastern work force (or beyond), employed workers and their representatives lose leverage; employer proposals to keep plants open in return for major concessions in the terms of employment are difficult to resist. ${ }^{2}$

\footnotetext{
'We focus on the firm and plant levels, the essential locus of interaction between codetermination and collective bargaining in Germany. An examination of employer associations, union federations, and national unions is important for future research but beyond the scope of this study.

2 The official unemployment rate for eastern Germany had reached $16.5 \%$ by January 1992 . But over half a million workers were still receiving
}

On the other hand, the spread of West German institutions to the East, again on the basis of political decision, has created new opportunities for interest representation. Under the Works Constitution Act, works council elections are required in every workplace with five or more employees; and the newly elected works councillors have specific legal rights to information, consultation, and, in critical matters such as personnel policy and incentive systems, codetermination (veto rights in management decision-making). ${ }^{3}$ Western unions were quick to move into the East and sign up new members; eastern work force activists interested in running for works council or union positions have been equally quick to join the western unions. For both institutional and political reasons, German businesses cannot employ a nonunion strategy like the Southern strategy of U.S. employers as German capital moves East. Unions have signed up new members in great numbers (the IG Metall, for example, grew from 2.6 to 3.6 million members from 1990 to 1991; Fichter 1991:31); included in these numbers are most works councillors, who now find themselves with important legal rights at a time when management must reorganize work extensively.

Market and institutional forces, then, are pushing to a significant extent in

short-time compensation, a disguised form of unemployment insurance (Week in Germany, February 7, 1992, p. 4). German research institutes were predicting a rise in unemployment in the new eastern states to $20-28 \%$ or more (European Industrial Relotions Review, Vol. 215, December 1991, p. 14). In the meantime, it was clear that without a "massive application of employment policy instruments" (such as short-time, early retirement, job creation, and full-time training), unemployment would be close to 40\% (Employment Observatory: East Germany, May 1992, p. 3). Particular groups such as workers over 55 and women were especially hard hit. By April 1992 , for example, women accounted for $62.9 \%$ of the unemployed in the East (Ibid., p. 2).

3 The Works Constitution Act, passed in 1952 and amended in 1972, is the basic national legislation that establishes and regulates works councils. For useful English language introductions to codetermination and industrial relations in the Federal Republic of Germany, see Streeck (1984) and Berghahn and Karsten (1987). 
opposite directions. ${ }^{4}$ In this open period of transformation, we argue that different outcomes are possible, dependent in part on broader economic developments within the EC and Eastern Europe, but depending to a significant degree as well on actor strategy and choice: political decisions made by federal and state governments (and influenced by organized representatives of labor and management); strategies developed by employers and unions; the ability of each side to organize and mobilize; and the outcomes of bipartite and tripartite negotiations. In part because the great political transformation of 1989-90 (die Wende, as the Germans call it) caught all actors unprepared, the constellation of winners and losers, of risk and opportunity, was and remains open to an extent quite unusual in political, economic, and social history.

\section{The Argument Situated}

Two views predominate in the discussion of the current transformation in eastern Germany. One view holds that as western institutions and markets are trans. ferred to the East, it is only a matter of time (5-10 years) before unified Germany will look just like the former West Germany. This was the view of the government and the leading economic research institutes in the first two years after the wall came down (1990-91). But this view, based on shaky econometric projections, downplayed the profound social, economic, and political dislocations taking place in the new eastern states and has been increasingly discredited by the facts. A 1992 estimate from the German Institute for Economic Research in Berlin, in fact, claimed that it will take 20 years to bring eastern German standards of living up to western levels. ${ }^{5}$

Another view is more pessimistic, for the eastern economy in general and for German unions in particular (Mahnkopf

\footnotetext{
'In can be argued, however, that markets are themselves institutions that vary cross-nationally in structure and organizing rules (Hall 1986: 35-36).

${ }^{5}$ Weeh in Gemmany, February 14, 1992, pp. 4-5.
}

1991). In this view, the unions, surprisingly resilient in the past, will finally be overtaxed and unable to overcome the tensions and contradictions within an east-west segmented economy and work force. What remains of the eastern work force may simply be organized into extended assembly lines for more advanced western plants (Voskamp and Wittke 1991), while eastern Germany becomes a long-term less developed region (a permanent Mezzogiorno) for Germany as a whole. Able to play eastern and western work forces off against each other in order to secure concessions, German employers will increasingly dominate German industrial relations while German unions finally experience the decline so common to other advanced industrial societies.

Our view is situated between these two perspectives. Neither institutions nor markets, we argue, can simply be transferred from west to east. Institutional transfer, as always, must build on existing materials. This was true for postwar Japan and West Germany (where institutional reconfiguration was based on established demands or traditions such as employment security and works councils, respectively; one did not simply build anew); and it is true today throughout Eastern Europe (Stark 1992). Institutional transformation, therefore, includes much conflict and negotiation, in processes that include both substantial risks and positive opportunities for innovation. Not only will industrial relations in eastern Germany be transformed, but the tensions and new outcomes will very likely transform industrial relations in all of Germany, in quite unpredictable ways.

But we are not just hedging our bets. We expect that German unions, as organizations, may do reasonably well in extending their influence into the East, and that workplace codetermination, at least as it is practiced in the West, will, after a transition period, be firmly established there. These outcomes will result from the leverage afforded unions by entrenched (West) German institutions of codetermination and nationally coordinated collective bargaining. Our causal argument (emphasizing institutional transfer), our 
conceptualization of the process of change (beginning with pre-existing material, including institutional remnants), and our cautiously optimistic predictions for the future of German unions and industrial relations are based on the findings of our present research.

\section{The Findings: A New Framework for Industrial Relations}

Economic disaster, at least in the short run, has been the dominant post-unification reality in the new German states. The collapse of production and employment in the former GDR began with economic and monetary union on July 1,1990 , and continued with the collapse of Eastern European and Soviet economies, as the products of eastern industry faced both the loss of traditional protected markets in Eastern Europe and new competition at home from more desirable western products. By winter 1991, vast permanent reductions in personnel had taken place throughout the economy, especially in manufacturing; and in major branches of the economy, over $50 \%$ of the work force was on "short-time work" (Kurzarbeit), most of these still paid but not working at all. The Treuhandanstalt (the governmentestablished agency in charge of the former GDR's economic assets) hoped to stimulate market-led firm restructuring by an emphasis on privatization and massive personnel reduction. Many eastern firms, spun off by the Treuhand from the large Kombinate (the vast integrated corporations of the GDR that included most economic and much social life), were in fact taken over by western firms through purchase or joint venture and converted at least temporarily into low-cost lengthened assembly lines for the core plants of the West.

The survival chances of eastern firms were greatly enhanced by takeover or close collaboration with western firms. Independent efforts were difficult both because the spunoff firms were burdened with a "fair share" of the huge debt of the former Kombinate, making new financing difficult to secure, and because the new firms lacked the latest technology and access to Western markets and therefore needed some kind of fusion with market leaders.

One of the major actors in this transition period is the Treuhandanstall, through which government economic policy in the eastern states is implemented. The Treuhand's mission is threefold: to privatize, to restructure and redevelop, and, where appropriate, to liquidate. Within the Treuhand, there has been considerable debate over questions of strategic orientation. Although some have called for a focus on proactive restructuring (or "redevelopment"), in practice the upper hand has gone to those who see privatization as the quickest path to restructuring. ${ }^{6}$

Unions along with works councils at the large Treuhand-controlled firms have sharply criticized the Treuhand for two reasons: the absence of codetermination in strategic decision making (especially for works councillors, who claim that their many ideas for firm restructuring are typically ignored in Treuhand decisions); and the weak emphasis on proactive restructuring and redevelopment, resulting in a rush to lay off workers. ${ }^{7}$ By the summer of 1991, under pressure from unions, works councils, and political parties, the Treuhand had begun to alter its course somewhat: a negotiated agreement on the establishment of employment and training companies (BQGs: Beschäftigungs- und qualifizierungsgesellschaften) for the displaced, spun off from Treuhand firms, led to the rapid spread and growth of $B Q G s$ in the new eastern states (see below);

\footnotetext{
${ }^{6}$ By February 1992, the Treuhand had privatized about half of its holdings (Week in Gemany, March 6, 1992, p. 5) and cut the total work force at jts firms by about half (see projections in Küht et al. 1991: 503). After subdividing the former Kombinate, the Treuhand ended up with 10,537 firms under its control (Treuhandanstalt 1991: A).

${ }^{7}$ As an example of the speed of privatizationdriven restructuring and its accompanying turmoil for eastern work forces, the case of Maschinenbau Takraf, a machinery building firm in Leipzig, is widely cited. In June 1990, the firm had 58 workshops employing 30,000 workers; by October 1991,5 plants remained, employing a total of 10,000 workers (Stiddeutsche Zeitung, October 26-27, 1991, p. 35).
} 
and labor's influence appeared to grow on the state-level Treuhand advisory boards. ${ }^{8}$ Most controversially, the Treuhand, both at the firms it has privatized and at those it continues to control, has organized massive layoffs and short-time assignments throughout eastern Germany.

Managers, also among the major actors in the transition period, are attempting in one way or another to reorganize production to improve productivity, product quality, and firm profitability. Where firms have acquired western investment or ownership, top western managers have usually taken over. Although the Treuhand drastically reduces personnel prior to the new investment (in an explicit deal), the ranks of middle management remain dominated by the so-called "old red socks." These cadres from the old system are now supposed to preside over innovations in production processes; but relations between these middle managers and their work forces are not always harmonious. Five of the six firms we studied remained at least partially controlled by the Treuhand in this transition period (1991-92)-a pattern that appears typical throughout the former GDR-further limiting managerial discretion in many cases.

Works councils are brand-new institutions in the eastern workplaces. Under the old system, each workplace had a plant union committee (BGL: Betriebsgewerkschaftsleitung) dominated by communist party members and working closely with management to implement state-established economic and social goals. The BGLs were

\footnotetext{
${ }^{8}$ The Treuhand has a supervisory board (Verwaltungsrat) that includes four labor representatives. But the unionists, in a minority position, have not had much influence except in special circumstances. During the Hennigsdorf steel strike, for example, intense outside pressure made it possible for unionists on the board to push through some of labor's demands (concerning employment levels, BQG support, investment, and other personnel issues) for that specific case. Although labor's voice has, on the whole, been rather weak at the central level, the Treuhand also has advisory boards for each individual state (Beratungsgremien ouf Lönderebene), and at this level unions have become increasingly influential since the summer of 1991 .
}

eliminated in 1990 and replaced with interim elected union groups until works council elections could be held following unification (October 1990) and the spread of western law to the East. Among the ranks of the newly elected works councillors are some old BGL members, some middle-to-lower-level union activists from the old system, some fresh faces, and, in a very few cases, experienced westerners who have come in and been elected to help set up the new works council. Challenges facing these overtaxed bodies include learning their new rights and responsibilities under the Works Constitution Act (for which, in many cases, they received early training from western unionists); negotiating the terms of massive layoff; and negotiating with management the terms and shape of new production and work organization.

The unions from western Germany have moved rapidly into the East to take over functions of collective bargaining and union representation. At the firms we examined, the IG Metall, the largest of the western unions, had quickly established high membership density and provided works councillors with training for their new roles. At the regional level, the IG Metall negotiated collective bargaining agreements with employer associations that gave eastern workers either $62 \%$ or $68 \%$ of western pay levels in 1991 , with an agreement to reach wage parity by 1994 and work hours parity by 1998.9

The old eastern IG Metall (IGM-Ost) was dissolved in 1990 , and the incoming union made the controversial decision to exclude, at the outset, all IGM-Ost staff from the new union offices (to root out former secret police agents). ${ }^{10}$ The heads of local and dis-

\footnotetext{
${ }^{9}$ Parity, however, is an elusive goal. Actual wage and benefit levels are even lower than the $62-68 \%$ levels, when all things are considered (WSI. Mitteilungen, August 1991). Workers in the East, for example, are often placed in lower job categories than comparable workers in the West; and in the public sector, workers have lost much of their pay-determining seniority. Real parity will not be achieved for many years to come.

${ }^{10}$ Other unions, such as the chemical workers, took a different approach, incorporating to some
} 
trict offices of the IG Metall in eastern Germany are now in most cases westerners, although former IGM-Ost leaders and activists have been integrated and play important roles throughout the union hierarchy. To expand into the East, the IG Metall created 34 new local offices; at the regional level, the union created one new district (Dresden) and expanded four others (Berlin, Hamburg, Hannover, and Frankfurt) to cover the new eastern states (Kittner 1991: 74-78).

Finally, the work force, that portion not already laid off, finds itself under enormous labor market pressure. High unemployment levels, both official and disguised, will no doubt last for years. Many of the remaining jobs are undesirable ones; skilled workers continue to migrate westward; older workers are forced out of the work force; women bear a disproportionate share of the unemployment burden as many are, in effect, sent home to care for the children, thereby leaving jobs to the male "breadwinners"; and workers in general have been completely unprepared for the sudden events that have drastically altered their working lives.

The situation in 1991-92, to many workers and work force representatives, appeared extremely difficult. As the Treuhand continued to sell off or close down plants with little regard for short-term employment effects, western investors demanded major work force concessions at the former GDR plants. Unions and works councils were preoccupied with internal structure and with the social effects of rationalization and plant closings. And by mid-1992, it became clear that perhaps the biggest problem, and the major source of massive unemployment, was the inadequate level of private western investment in eastern Germany. "I

extent the eastern counterpart union into the surviving western union (Kittner 1991:77-78; Fichter 1991).

11 Private investment in eastern Germany was estimated to be around DM 32.5 billion in 1992 , compared to DM $\mathbf{5 4 . 5}$ in public investment (for telephone, postal services, roads, railroads, and so on); and the per capica level of private investment for 1992 was projected at one-third less in eastern than in
With the expiration of IG Metall-negotiated employment security on June 30,1991 (although government-financed short-time pay was temporarily extended), an enormous unemployment crisis loomed. In such loose labor markets, the dominance of western capital in the industrial arena appeared fundamentally unchallenged, in spite of high union membership levels and active new works councils. Individuals with the independent capacity to articulate interests were rare: coming from the West, they may have had clean, uncompromised histories but often found little acceptance in the East; coming from the East, they had typically made their careers under the old regime. The IG Metall's honeymoon period in the East was clearly drawing to a close; works councillors repeatedly criticized western-led union policies and contract settlements as insensitive to the problems faced by their own work forces. After a year or more in office, many works councillors were disillusioned by what had become their primary task: negotiating the terms of massive unemployment.

But we saw positive signs as well. In each of the six cases we studied, union membership density in 1991 was $90 \%$ or above, matching or exceeding rates at comparable plants in the West. ${ }^{12}$ Shop steward structures, based on rank-and-file elections, existed or were in the planning stages, in collaboration both with local union offices and with works councils. Works councillors, although anxious and under great stress, were nonetheless in some cases still hopeful about what they could accomplish, and actively engaged

western Germany (Der Spiegel, June 15, 1992, pp. 100-103). Reasons given for unexpectedly low levels of investment include low productivity and consequent high unit labor costs, unresolved property ownership questions and claims, and inadequate infrastructure and institutions.

${ }_{12}$ Membership density, to be sure, is not the same thing as organizational strength. Many eastern workers were resigned to very difficult circumstances and saw union membership as an insurance policy, especially in the event of threatened unemployment. This situation, of course, is not unlike what one often finds within the traditional unions of western societies. But by 1992, although no broad data were yet available, membership rates appeared to be dropping; certainly there was a decline at several of the plants we visited. 
with both management and the work force on a number of fronts. The works councillors we interviewed had all been through IG Metall training programs to learn the rights to information, consultation, and participation granted them under the law (although they were also disappointed by the limitations of those rights). After the layoffs and mass dislocation, the remaining workers appeared eager to learn and to show that they could produce at western levels if given the chance (with appropriate technology and organization). We found works councillors and managers collaborating on new work organization that in some cases included shopfloor innovations such as teamwork. And we found examples of close EastWest collaboration within union offices and works councils and in works councilunion relations.

\section{The Findings: Four Types of Firms}

More important than distinctions of sector, product, or process in this transition phase appeared to be prospects for firm survival and future production. On this dimension, we have identified the following four types of firms.

(A) Firms taken over by a major western multinational corporation and integrated into a worldwide or Europeanwide corporate strategy. These firms have a high probability of success, with production profiles dependent on strategic decisions at corporate headquarters.

(B) Firms linked directly to western investment, through ownership or joint venture. These firms are integrated into western market and production strategies and have at least the possibility of modernization through new investment.

(C) Firms spun off from the large Kombinate and seeking either western partners or survival as independent units.

(D) Firms going under.

Although we gathered background in- formation on many firms, we decided to focus on six representative case studies, to examine industrial relations developments in detail. We chose one firm of type A, two of type B, two of type C, and one of type D. The firms we looked at were in the automobile, heavy machinery, and electronics sectors. ${ }^{13}$ In each case, the work force had elected new works councillors under the Works Constitution Act of the Federal Republic, and workers in large numbers had transferred union membership from IGM-Ost to the western IG Metall. These are all large firms, parts of the former Kombinate, but large firms are typical of current industry structure in the new federal states. In this study, we did not look at small and medium-sized firms, although what happens to these firms as they emerge (they hardly existed in the past in the sectors we have looked at), their networks, and their relations to larger firms are crucial subjects of study for continuing and future research.

From what we learned of other plants and firms both before and after our initial case studies of June 1991, we believe that the four types we have identified are broadly characteristic of firms in eastern Germany, at least in manufacturing.

\section{Types A and B: Recipients of Western Investment}

Type A and B firms, usually through takeover, have received substantial investment from a western firm. Prospects for survival are good, but only after major restructuring. After currency union (on July 1, 1990, when GDR marks were

\footnotetext{
13 Our research was interview-intensive, conducted for the most part in June 1991, with follow-up interviews in June 1992. We visited each firm at least twice and used an open-ended, intensive interview approach with a timited number of well-placed subjects. We conducted 32 interviews in all, typically $2-3$ hours in length. The majority of our interviews were with elected works councillors, well placed for our purposes between employer and union; but we also conducted several interviews both with managers and union representatives. Although we promised confidentially to our interviewees (for obvious organizational reasons), we can supply the names of the firms, upon request, to interested researchers.
} 
converted to western marks), these firms typically lost much of the market for their products, which meant large-scale reductions in personnel, product offerings, and research department size. In all cases, most remaining workers have joined the appropriate western union (for our three cases, the IG Metall) and participated in the election of new works councillors.

Although sóme former (BGL) union leaders have been elected to works council positions, most of the new works councillors are former low-to-middle-level union officials or new faces. These works councillors, without exception, have shown an active interest in working with management to restructure the firm and expand production. They have received works council training from the IG Metall and intend to use codetermination rights to the fullest. They are disappointed that those rights are limited to information and consultation in important matters such as strategic planning and investment decisions; but they have engaged themselves with western managers, local managers, western works council counterparts, and IG Metall representatives in an attempt to gain maximum leverage.

Four goals that the new works councils have particularly emphasized are (1) mobilizing the work force to work hard and flexibly, to convince top western management to invest more in their plants; (2) obtaining new technology and training for the work force; (3) developing and presenting to management new ideas for production (for both product and process), based on past experience and established work patterns and potential in the plants; and (4) promoting the development of employment companies (BQGs), to employ and retrain displaced workers. The first goal obviously provides a solid common ground for labor-management collaboration, which appears strong at these plants in spite of works council dissatisfaction with the management response to the second, third, and fourth initiatives.

The type $A$ firm we visited is an auto producer in Saxony. In this case, a large (West) German auto firm bought a plant where East German autos were produced until 1990. By mid-1991, this multinational firm had rehired 1,250 workers (from a pool of 12,000 former workers at this and nearby plants of the same Kombinat) and begun to produce western model cars. In the meantime, the firm is building a new plant, scheduled to open in 1994 , adjacent to the currently functioning one; personnel plans include gradual additional hiring to reach a 1994 total of 5,500. Long-term investment here appears secure.

Top plant and firm management (the firm is structured as an independent subsidiary of the parent firm) are excited about the new operation here, viewing it as an opportunity to introduce innovations. From both management and the works council, we heard this plant referred to as a sort of eastern NUMMI. ${ }^{14}$ Management intended, for example, to introduce early on a comprehensive structure of 8-12-member workteams; and works councillors were hopeful about the development of a new type of mitwirkender Mitarbeiter (engaged co-worker, or team worker).

Although top management is from the parent firm, most middle-level managers come from the ranks of the former managers from the communist system. The parent firm has done assessment testing and screening and is convinced that many of the former managers are flexible and can function well, with retraining, in the new environment. Top management was also pleasantly surprised by the skills and flexibility of the existing work force.

Newly elected works councillors come mainly from the ranks of former low-tomid-level union activists. Prior to the election (in April 1991), however, these activists sought out a westerner to help them learn how to negotiate under the Works Constitution Act with an experi-

\footnotetext{
${ }^{14}$ New United Motor Manufacturing (NUMMl) is the acclaimed GM-Toyota joint venture plant in Fremont, California, that achieved path-breaking productivity and quality levels using innovations such as shopfloor teamwork (Turner 1991: 53-62).
} 
enced western top management. Through the IG Metall they found an experienced works councillor, from a western plant of the parent firm, who was willing to get involved. The firm was persuaded to put him on the books so that he could run for office on the works council, to which he was elected with the highest number of votes. The new works council chose him as chairperson; and the newly elected group began the task of coalescing as a leadership team and beginning to analyze information and negotiate with management. The new works councillors received training from and stayed in close contact with both the IG Metall and the parent firm's general works council in the West.

With investment secured and solid prospects of continued hiring, the mood here was upbeat. Works councillors criticized IG Metall's regional contract, which would keep their work force underpaid relative to western counterparts for years to come (with lower pay, fewer holidays and vacation days, weaker benefits, and smaller bonuses). But they all belonged to the IG Metall and looked to the union for support, as did virtually the entire work force. Labor-management relations appeared quite positive: management was hopeful that the works council would be willing collaborate in the development of innovative production organization, and works councillors intended to use their legal rights and bargaining power to press for human-side concerns based, for example, on the IG Metall's principles of group work (such as a broad assignment of varying tasks: see Muster and Wannöffel 1989; Turner 1991: 113-14). Both sides were hopeful that this plant could stimulate the development of a modernizing network in this area of Saxony.

At type $B$ plants, the going was more difficult. In this category were a producer of brake parts and a producer of power plant machinery, both headquartered in eastern Berlin. Both firms had been taken over by a western producer of similar products. In each case, works councillors were preoccupied both with the joint effort with local management to secure new technology and training for local plants and with the effort to build employment companies for the displaced.

Again, plant management consisted mainly of former communist managers, whereas the newly elected works councils included a mix of former union leaders and new people. At one of the firms, the former BGL leader had survived to head up the new works council (where five of the fifteen elected members came from the old $\mathrm{BGL}$ ); at the other firm, a former BGL member (who had nonetheless never been a party member) was elected to head the new works council, to which most former union leaders were not elected.

Although works councillors at both firms had joined the IG Metall and claimed to have good relations with their western counterparts, their role, they told us, was quite different from the usual role of western works councillors. In their case, the primary task was to work with management (both local and from the West) to convince top western executives to increase investment in these eastern plants. They mobilized their work forces to work hard and flexibly, prepared to make a variety of concessions, and gave ideas to management regarding product and process strategies. In their willingness to make concessions (such as weekend work and night shifts) and their close collaboration with management, they came into conflict at times with representatives of the IG Metall and western works councils.

Although they valued union membership for the training and other support offered and for the long-term prospects for collective bargaining, works councillors at both firms voiced the complaint that "Wessi" unionists did not understand their problems. To a large extent, they had to fall back on their own resources, to work with management to solve their own firm and plant problems. They were disappointed that their input had largely been ignored by the Treuhand in its decisions regarding layoffs, product strategies, production organization, and firm sale; and they complained that their voice had been minimal in regional-level IG Metall strategy and leadership selection. They claimed to have an important contri- 
bution to make based on their experience and work relations in the plants, a contribution they were now making to some extent in local and corporate labormanagement relations. Management at both firms, especially top management, appeared to rely on the works councils to contribute ideas and help organize the work force.

\section{Type C: Independent Survivors}

Type $C$ firms are firms spun off from the old Kombinate by the Treuhand and attempting to restructure and survive on their own, with no major western investment in the short run. ${ }^{15}$ Because their ideas for restructuring received little support during the Treuhand's period of control, these firms lost valuable time and market share. These firms are characterized by insecure management; westward migration of highly qualified white- and blue-collar workers; wide fluctuations in performance and prospects; confrontation between management and works council over both control of the firm and the social demands of the work force; and the decentralization of the firm into profit centers or other units, fighting for survival at that level.

The type $\mathrm{C}$ firms we visited were an electronics engineering firm in eastern Berlin and a large auto firm in Saxony. The electronics firm had been subdivided into 16 profit centers (with the help of western consultants), each now struggling to develop products, show profit, and acquire targeted investment. Elected on the basis of the profit center structure, the works council, along with top management, was the only firmwide body and therefore played an important role in shaping company policy. All former union leaders had been swept aside in works council elections, making this the only old-red-socks-free works council in our sample. The new works councillors claimed to have as much influence in developing firm

${ }^{15}$ Of 2,400 sales reported by the Treuhand as of September 1991, 653 were management buy-outs (Treuhandanstalt 1991:1.20) that fit into this category. product strategy and process innovation as company management. Relations between labor and management were thus very close but also tense, since it was not at all clear just who was in charge.

Because the last East German autos had already rolled off the line, the auto firm in Saxony was desperate for new product strategies and grasping at many different straws. The old $B G L$ leader had survived politically to be elected head of the new works council; he now worked closely with management to decide such questions as which auto parts the firm could continue to produce and which parts of the firm could be viable.

A major preoccupation at both of these plants was the establishment of employment companies, to use unneeded or obsolete resources of the firm to provide jobs and training (and perhaps even sustainable production strategies) for the many displaced workers. Our 1991 visit to the firm in Saxony, in fact, coincided with a highly publicized plant occupation there by a thousand workers, protesting Treuhand policies. It was in the wake of this clash and other protests and occupations that the Treuhand negotiated, with unions, employers, and state governments, its compromise agreement on the establishment of employment companies (see below).

By the summer of 1992, one of these type $\mathrm{C}$ firms was in the process of being taken over by a group of western investors; the other was actively seeking such western investment. Although cases of successful management buy-out can be found in eastern Germany, independent survival proved impossible in the end for the two cases we looked at-which, we suspect, are quite typical.

\section{Type D: Firm Failures}

In this category are firms with products that proved obsolete after the Berlin Wall came down. In these cases, the Treuhand has orchestrated liquidation; employees received short-time compensation while either staying home or seeking new em. ployment (for most, short-time pay lasted until the end of 1991); and work force 
representatives were preoccupied with negotiating employment and training opportunities for the displaced work force. In many such firms, new works council elections took place even as liquidation proceeded.

The one type $D$ firm we visited was a producer of consumer electronics goods that simply could not begin to compete with western radios and stereos. Various attempts were made under a succession of top managers to salvage the firm by securing western investment and shifting to new products. After these attempts failed, machinery was sold off and the buildings were sold.

The former BGL union leader managed to survive politically as the newly elected chair of the works council. In the final months of the firm's life, he and the other works councillors put their main efforts into negotiating work force protections in the face of imminent mass layoffs. The works council secured employment commitments for 700 workers (out of a total 1989 work force of 3,200 at the electronics company). And the works council also secured the establishment of an employment and training company, which the works council chairperson would now direct and which could employ several hundred more displaced workers. In 1990 , most of the work force had joined the IG Metall, which had given training to the new works councillors and supported the establishment of the employment company.

\section{Findings: The Politics of New Work Organization}

What kind of work organization will emerge as a general pattern in the new states-advanced and innovative or traditional-is a question that remains unresolved. In two of our six cases (the type A firm and one of the type $B$ firms), employers appeared determined to bring in advanced technology and flexible work organization, and to use the eastern plants for modern, up-to-date production. In these cases, management relied on skilled, flexibly deployed work forces. In the remaining cases, the outlines of projected production strategies were still unclear.

For many works councillors, a major problem was the prevalence of the former managers in the ranks of the "new" middle management. ${ }^{16}$ Where firms have secured substantial western investment, top western managers have decided, on the basis of testing and experience so far, that many of these individuals are quite suitable for current management responsibilities. Although experienced in manag. ing eastern work forces, these middle managers are in some cases widely disliked by their employees. As studies in the United States and other countries have shown, new approaches and attitudes on the part of middle managers are critical for the success of work reorganization strategies, especially when those strategies call for a more committed work force and new relations of labor-management collaboration and trust (Kochan, Katz, and McKersie 1986; Milkman 1990; Turner 1991).

\section{Union Prospects}

Works council-union relations are and will continue to be difficult. The tensions inherent in a system of dual representation, including dangers well known in the West such as "plant egoism" (manifested when works councils put the interests of their own plant over broader union and working-class interests: see Windolf and Hohn 1984; Hohn 1988), can only be magnified when union leadership from one political culture encounters works council leadership from another.

Although we heard works councillors express pride in their new IG Metall membership and appreciation for the support they had received in matters such as training, we also heard of western paternalism and a lack of understanding

\footnotetext{
${ }^{16}$ Some of the works councillors we interviewed are, to be sure, old red socks themselves. And many of these former functionaries in labor and management have both expertise and a genuine willingness to contribute to the new system. But getting beyond the old and more recent wounds to work together in new ways is a protracted process, and one that permeates contemporary eastern German society.
} 
of the problems of eastern work forces. Works councillors, for example, who wanted to allow their work forces to work three shifts and weekends (and claimed work force support for such efforts to prove that their plant deserved to remain open and receive new investment), complained of IG Metall interference. ${ }^{17}$ Newly elected works councillors, as we have seen, also complained that regional-level contracts will keep them a second-class work force through the end of the decade. And works councillors at several firms claimed that at the upper levels the union is not democratic, that their concerns are not taken into consideration, and that internal processes remind them in some ways of the old East German unions.

In spite of its rapid growth in membership, therefore, the IG Metall is far from secure in its position in the new states. Works councillors at type B and C firms said they would do what was necessary for their own work forces regardless of the wishes of the national union; and they claimed the support of their own work forces for such action. Some predicted that union membership, after the initial rush to join based both on insecurity and hope, would decline to more "realistic" levels in the face of disillusionment with union policies.

We did not find the commonly depicted passive eastern work force, demoralized and used to doing what it is told after 40 years of communism. In fact, we found generally skilled work forces used to improvising and problem solving within inefficient economic structures (see also Kern 1991; Voskamp and Wittke 1991). Workers, at least as reported by their elected works councillors, wanted more influence on work organization in the new system; and they wanted more rank-and-

\footnotetext{
${ }^{17}$ In a long-standing policy, popular in the West, the IG Metall opposes except in exceptional circum. stances both three-shift and weekend work. The latter has been a postwar sacred cow for the West German labor movement; and the "free weekend," so the argument goes, can only be maintained if it is defended across the board. Weekend work regulations have nonetheless been loosened in recent years in the West in plant-level agreements.
}

file democracy within the union. In some cases, they were ripe for spontaneous mobilization, as numerous plant occupations in 1991 indicate.

What role will these workers play in their new unions in the future? Some have argued that the conjunction of western unionists bringing their new mission to the East and encountering vast passive work forces will seriously set back western processes of internal union regeneration and democratization (Mahnkopf 1991). ${ }^{18}$ Other outcomes, however, are clearly possible. Eastern workers may, if they encounter western union leaders whose condescending treatment reminds them of their old union bosses, simply drop out of the unions. On the other hand, these eastern workers, and especially their elected shop stewards and works councillors, may join the push for what the Germans call Basis-Demokratie (grass-roots democracy). Several times in our interviews, we heard from works councillors that they and their colleagues would either hold the union at a distance or fight within for reform and democratization. It is not inconceivable that eastern workers, fed up with paternalism and authoritarianism from any source, could become important allies of those in the West promoting internal union democracy.

\section{Active Labor Market Policy: Employment Companies}

The campaign for employment and training companies (BQGs) provided a major focus for union and works council mobilization in 1991. Works councillors at every firm we visited were pushing for the establishment and funding of employment companies to provide job creation and retraining for the displaced. In the spring and summer of 1991, the Treuhand, as the primary agent responsible for laying off workers, found itself under great pressure to support the BQGs. The

\footnotetext{
${ }^{18}$ Mahnkopf also argues persuasively that the growing environmental emphasis of western unions could fall victim as well to the more immediate economic needs of eastern workers.
} 
pressure was internal, from works councils at Treuhand-controlled firms and from workers who in some dramatic cases occupied plants to press their demands, and external, from the unions and state and local governments. Wary about the impact of such publicly financed companies on the broader goal of rapid privatization, the Treuhand nonetheless accepted the $B Q G$ concept as a way to soften the impact of massive layof $\mathrm{s}$.

The idea behind these companies is to combine unused plant (buildings, machinery) with laid-off workers to set up temporary production and training that could lead to new jobs for the displaced. The major source of funding for the $\mathrm{BQGs}$ is the Federal Labor Bureau (BA: Bundesanstalt für Arbeit), which, because of the magnitude of its payouts for unem. ployment, short-time work, and now the $B Q G s$, has become quite important in the new eastern states. Heinrich Franke, BA president, argued (in opposition to Jürgen Möllemann, the Economics Minister) that the $\mathrm{BQGs}$ are in a broad sense revenueneutral, since employees do not get unemployment benefits and do produce and pay taxes. ${ }^{19}$

In July of 1991, Treuhand-union negotiations finally resulted in a framework agreement for the establishment of the companies, diffusing the conflict. ${ }^{20}$ In return for official support for this major policy goal, unions conceded to the Treuhand the principle that the BQGs would be separate entities with no formal ties to or claims on the firms from which workers were laid off. Including active participation by employer associations, state governments, and unions, the BQGs offer the possibility of substantial adjustment assistance and retraining for eastern workers along with a new "social partnership" role for the unions.

In the wake of the July agreement, employment companies have been established throughout eastern Germany and have become an important labor market

\footnotetext{
${ }^{19}$ European Industrial Relations Revieu, Vol. 215, (December 1991), p. 15.

${ }^{20}$ Week in Germany, July 26, 1991, p. 4.
}

feature in which unions play an active role. The critical question for the future of these companies and for the gains that unions hope to make by their participation is: will the BQGs result in real job creation and training, or will they serve mainly to disguise long-term unemployment? At the very least, these companies cushion unemployment in the East-and for that the unions can take credit, since employment companies were very much their idea.

\section{Contending Scenarios}

For the economy of the five eastern states, our findings show indications of two contrasting developmental scenarios. In a modernization scenario, investors make use of the advantages of backwardness (Gerschenkron 1962) to spur new growth in the former GDR. Because much of the old plant and organization must be cleared away, employers are in a position to bring in the latest technology and production concepts. They could, for example, adopt elements of "lean production" (Womack, Jones, and Roos 1990) in greenfield and semi-greenfield settings, in collaboration with flexible work forces eager to train for advanced technology and work under innovative organizational conditions in the drive to secure jobs and steady income. In the best case, new production concepts, rather than starting from scratch, could build on the problemsolving and collaborative traditions of a skilled and flexible eastern work force (Kern 1991; Voskamp and Wittke 1991). In such a setting, one could imagine modernization advances over existing practice in western Germany that would turn the ex-GDR into a growth region.

One can also imagine, however, a polarization scenario, in which the eastern states of unified Germany occupy the lower end of a dual economic and social structure. In this scenario, Western firms invest in the East but only enough to exploit the old structures, including outdated mass production lines. Using more pliable work forces and lower labor costs, Western firms establish in the eastern states an extension of their assembly 
operations (Mahnkopf 1991; Voskamp and Wittke 1991). The brain drain would continue as the most highly skilled eastern workers seek better opportunities in the West. And the established western states of unified Germany would use both new demand in the East and favorable production terms for firms doing business there to spur the further modernization of the West-in this case at the expense of the East. Union strategies to bargain for phased-in wage parity have aimed in part at heading off this potential scenario (although such strategies may simply deflect "Maquiladora" locations to the Polish border area, leaving much of eastern Germany in a sort of economic development limbo). 21

Industrial relations prospects follow from broader economic development scenarios. The first scenario could include innovations in work organization, including new forms of labor-management collaboration. Managers could introduce more flexible working arrangements; works councillors could engage in decision-making processes to promote "humanization" aspects of new work organization; and workers could claim more shopfloor autonomy and problem-solving independence. Innovations such as unionemployer negotiated group work could spread more quickly than is possible in the West, where, in spite of active efforts to negotiate change on the part of both labor and management, entrenched structures and interests often stand in the way. ${ }^{22}$ To use Olson's terminology, "institutional sclerosis" in the East would be cleared away, making innovation and new growth

${ }^{21}$ Because productivity is much lower in the East than in the West, unit labor costs are higher in the East in spite of overall wage levels about half as high. This hejps to explain the much lower-than-hoped-for levels of private investment so far in the East. Both modernization and polarization scenarios require rapidly rising productivity in the East.

${ }_{22}^{2}$ It is also possible that modern group work could build in part on the eastern tradition of "brigade organization," a structure of group organization in GDR workplaces. This subject is widely discussed among German industrial sociologists and an example of how new practices could build on institutional remnants from the old system. possible (Olson 1982). But (in contrast to Olson's argument) there is no necessary reason why this scenario could not build on existing institutional remnants and include strong unions and works councils actively engaged in management decision making.

The polarization scenario could also include labor-management collaboration, in this case based on weak workers' interest representation; or this scenario could include increasingly adversarial relations. Management would stand clearly in command, dispensing strenuous jobs to workers with weak (or at least unenforced) social and labor rights and little employment security; and management would be in a strong position to drive wedges between works councils and unions. Union membership density could be expected to drop off after the heady organizing period of 1990-91, as workers become disillusioned. The potential could be strong for outbursts of conflict between exploitative employers and their bitter work forces.

Government economic policy, Bundesbank monetary policy, and Treuhand strategies, to be sure, will play important roles in determining which scenario is dominant. What is actually happening so far in eastern Germany appears to include both scenarios, with one or the other more prevalent in particular areas, industries, and firms. This variegated picture will most likely persist for some time. The critical question, therefore, is whether enough modernization will take place in enough of eastern Germany to generate the networks of growth and innovation necessary to overcome polarization. If not, centers of innovation may well remain "cathedrals in the desert" (Grabher 1992), around which the dominant scenario will be what we have called polarization.

\section{Conclusion: Risks and Opportunities}

The evidence presented here has indicated both the risks and opportunities for German unions and industrial relations, and has pointed toward the causal forces 
at work. It is not just that institutions in the East have been scrapped, opening up new possibilities. That is part of the story, but a more complete answer recognizes two conflicting forces at work. The onrush of privatization and open markets is, on the whole, pushing toward outcomes that include weakened influence for workers' interest representation. Just as Reagan and Thatcher deregulation policies in the United States and Britain undercut the bases of union influence in those countries and contributed to union decline, so the Treuhand's neo-liberal policies have both kept the unions at arm's length and greatly strengthened the hand of management in eastern industrial relations. Massive unemployment has weakened union and works council bargaining power and offered employers an open choice between strategies of modernization and strategies of exploitation, with the latter becoming more tempting than ever.

At the same time, the spread of western institutions of interest representation to the East has given unions and works councils a strong toehold for present and future influence. The union organizational and political capacity to bargain for wage parity in the foreseeable future has undercut the attractiveness of old-plant, low-labor-cost strategies. And the Works Constitution Act, establishing democratically elected works councils throughout the eastern economy, has given work force representatives a platform from which to push for desired outcomes (modernization, high union membership density, better working conditions, and active engagement in management decision making).

Open markets, backed by conservative/ neo-liberal political decision, push in one direction; the spread of western institutions of interest representation (strong unions, codetermination structures, and rights) push in another direction. Thus, the German East has what the U.S. South has lacked: potentially positive prospects for unions even in wide-open economic circumstances.

It was the failure to appreciate the leverage afforded by particular institutions of interest representation (especially codetermination) that caused numerous German analysts to mistakenly identify or prophesize union decline in West Germany in the 1970 s and 1980 s. By the late 1980 s, the comparative strength of German unionism had belied these arguments; British and Italian unionists, for example, began to push for participation rights of their own, at home and at the European level. But German unification has given the pessimists new life. Although we may have been wrong before, they say, now German unions are really in trouble.

We argue, in contrast, that the spread of West German laws and industrial relations institutions to the East means that favorable outcomes are possible for interest representation, for production organization, and for the economic prospects of the new states. Possible, we argue, but not necessary. A great deal now depends on actor choice. If unions and works councils, for example, are flexible (as at our type A firm) and innovative (as in BQG development), they will improve the chances for a future of modernization and substantial union/works council influence in eastern Germany.

The interaction of markets, politics, and institutions is complex. It is especially complex in periods of institutional transformation, when outcomes are more open and undetermined than in periods of institutional stability. ${ }^{23}$ The current period of institutional transformation in eastern Germany will prove highly instructive for those who study political economy and fraught with both peril and opportunity for those who make history by building new institutions.

\footnotetext{
${ }^{29}$ For a useful discussion of the importance of institutions and institutional change, see Steinmo and Thelen (1992).
} 


\section{REFERENCES}

Berghahn, Volker R., and Detlev Karsten. 1987. Industrial Relations in West Germany. Oxford: Berg Publishing.

Busch, Ulrich, Michael Heine, Hansjorg Herr, and Andreas Westphal, eds. 1991. Wirkschaftspolitische Konsequenzen der deutschen Vereinigung. Frankfurt Main: Campus Verlag.

Employment Observalory: East Germany. 1992. Nos, 1-2 (March and May). European Commission, Directorate-General V/B/l.

Fichter, Michael. 1991. "From Transmission Belt to Social Partnership? The Case of Organized Labor in Eastern Germany." German Politics and Society, Vol. 23 (Summer), pp. 21-39.

Gerschenkron, Alexander. 1962. Economic Backwardness in Historical Perspective. Cambridge: Harvard University Press.

Grabher, Gernot. 1992. "Eastern Conquista: The 'Truncated Industrialization' of East European Regions by Large West European Corporations." In $H$. Ernste and V. Meier, eds., Regional Development: A Contemporary Response. London: Bellhaven.

Hall, Peter A. 1986. Governing the Economy: The Politics of State Intervention in Brilain and France. New York: Oxford University Press.

Hohn, Hans-Willy. 1988. Von der Einheitsgewerkschaft zum Betriebssyndikalismus: Soziale Schliessung im dualen Spstem der Interessenvertretung. Edition Sigma, Wissenschaftszentrum Berlin.

Jürgens, Ulrich. Thomas Malsch, and Knuth Dohse. 1989. Moderne Zeiten in der Automobilfabrik: Strate. gien der Produktionsmadernisierung im Linder- und Konzernvergleich. Berlin: Springer-Verlag.

Katz, Harry, and Charles F. Sabel. 1985. "Industrial Relations and Industrial Adjustment in the Cas Industry." Industrial Relations, Vol. 24, No. 3, Pp. 295-315.

Kern, Horst, 1991. "Die Transformation der östlichen Industrien: Soziologische Reflexionen über die Ex-DDR." Die Neute Gesellschaft: Frankfurter Hefle, Vol. 38, No. 2, Pp. 114-21.

Kittner, Michael, ed. 1991. Gewerkschaftsjahrbuch 199I. Cologne: Bund-Verlag.

Kochan, Thomas A., Harry C. Katz, and Robert B. McKersie. 1986. The Transformation of American Industrial Relations. New York: Basic Books.

Kúhl, J., R. Schăfer, and J. Wahse. 1991. "Beschäftigungsperspektiven von Treuhandunternehmen." MithAB, March.

Mahnkopf, Birgit. 1991. "Vorwărts in die Vergangen. heic? Pessimistische Spekulationen über die Zukunft der Gewerkschaften in der neuen Bundesrepublik." In Busch et al. (eds.), pp. 269-94.

Milkman, Ruth. 1991. "Labor and Management in
Uncertain Times: Renegotiating the Social Contract." In Alan Wolfe, ed, The Recentering of America: American Society in Transition. Berkeley: University of California Press.

Müller-Jentsch, Walther, ed. 1988. Zukunft der Gewerkschaflen: Ein internationaler Vergleich. Frankfurv/Main: Campus Verlag.

Muster, Manfred, and Manfred Wannöffel. 1989. Cruppenarbeit in der Automobilindustrie. Bochum: joint publication of the IG Metall Verwaltungsstelle Bochum and the Gemeinsame Arbeitsstelle Ruhr-Universităt Bochum.

Olson, Mancur. 1982. The Rise and Decline of Nations: Economic Growth, Staglation, and Social Rigidities. New Haven: Yale University Press.

Stark, David. 1992. "Path Dependency and Privatization Strategies in East-Central Europe." East European Politics and Sacieties, Vol. 6, No. 1, Pp. $17-54$.

Steinmo, Sven, and Kathleen Thelen. 1992. "Historical Institutionalism: State, Society and Economy." In Sven Steinmo, Kathleen Thelen, and Frank Longstreth, eds., Historical Institutionalism: State, Society and Economy. Cambridge: Cambridge Uni. versity Press.

Streeck, Wolfgang. 1984. "Co-determination: The Fourth Decade." In Bernhardt Wilpert and Arndt Sorge (eds.), pp. 391-422.

1987. "Industrial Relations and Industrial Change: The Restructuring of the World Automobile Industry in the 1970s and 1980s." Economic and Industrial Democracy, Vol. 8, pp. 437-62.

Treuhandanstalt Zentrales Controlling. 1991. Monats. bericht, September.

Turner, Lowell. 1991. Democracy at Work: Changing World Markets and the Future of Labor Unions. lthaca, N.Y.: Cornell University Press.

Week in Germany. New York: German Information Center, various issues, 1990-92.

Voskamp, Ulrich, and Volker Wittke. 1991. "Aus Modernisierungsblockaden werden Abwärtsspiralen: Zur Reorganisation von Betrieben und Kombinaten der ehemaligen DDR." Berliner Journal der Soziologie, Vol. 1, pp. 17-39.

Wilpert, Bernhard, and Arndt Sorge, eds. 1984. International Vearbook of Organizational Demactacy, Vol. II: International Perspectives on Organizational Democracy. New York: John Wiley \& Sons.

Windolf, Paul, and Hans-Willy Hohn. 1984. Arbeitsmarktchancen in der Krise: Betriebliche Rekrutierung und soziale Schliessung. Frankfurt: Campus Verlag.

Womack, James T., Daniel T. Jones, and Daniel Roos. 1990. The Machine that Changed the World. New York: Rawson Associates. 